\title{
Üniversite Dış Mekânları İçin Zaman-Mekânsal Haritalama Yöntemine Dayanan Bir Kullanım Sonrası Değerlendirme Modeli
}

\author{
A Post-Occupancy Evaluation Model Based On Spatio-Temporal \\ Mapping Method For University Outdoor Spaces
}

\author{
๑ Özgür GÖÇER, ${ }^{1} \oplus$ Kenan GÖÇER, ${ }^{2} \oplus$ Altuğ Melik BAŞOL, ${ }^{3} \odot$ Mustafa Furkan KIRAÇ, ${ }^{4}$

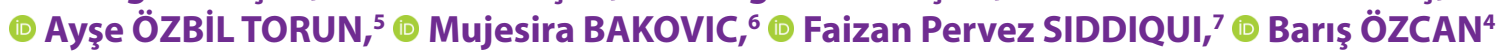

Öz

Üniversite yerleşkeleri yalnızca çeşitli sosyal ve eğitsel binalardan oluşmakla kalmaz, dış mekânları ve donatıları, rekreasyon ve peyzaj alanları ile bütünleşik bir kurgu oluştururlar. Dış mekânlar, yerleşke kullanıcılarının toplumsal etkileşim, dinlenme ve rahatlama, rekreasyon, fikir alışverişinde bulunma ve güçlü bir mülkiyet ve aidiyet hissi oluşturma potansiyeli taşırlar. İnsanların birbirleriyle iletişim kurmalarını ve sosyalleşmelerini sağlayarak sosyal yaşam için ortak bir kimlik oluşturmak dış mekânların en önemli işlevidir. Ne var ki dış mekânlar ne kadar akılcı tasarlansa da, uygulamada beklenenin dışında bir kullanımla karşılaşılabilmektedir. Beklentiler ile uygulanan arasındaki farkın belirlenebilmesi için dış mekânlar ile bina grupları arasındaki ilişki, yeterlilik, kullanım süresi, erişilebilirlik ve fiziksel çevrenin etkileşimi bütünsel bir yaklaşımla incelenmelidir. Dış mekânlarda insan kullanımının ve tasarım niyetinin başarılı olup olmadığını değerlendirmenin en iyi yöntemlerinden biri olarak kullanım sonrası değerlendirme (KSD) önerilmektedir. Ne yazık ki, iç mekânların değerlendirilmesine ilişkin KSD yöntemleri hakkında çalışmalar her geçen gün artsa da, dış mekânların değerlendirilmesine yönelik özellikle üniversite yerleşkelerinde uygulanabilecek kapsamlı bir KSD çalışmasına rastlanmamaktadır. Bu çalışmada dış mekân kullanımını etkileyen değişkenleri ve bu değişkenler arasındaki etkileşimi bütüncül olarak ele alan bir KSD yöntemi tanıtılmıştır. Önerilen yöntem kent dışı bir üniversite yerleşkesinde uygulanmış ve uygulama sonuçları dış mekân kullanım değeri bakımından değerlendirilmiştir.

Anahtar sözcükler: Dış mekan; kullanım sonrası değerlendirme; üniversite yerleşkesi; zaman-mekansal haritalama.

\section{ABSTRACT}

Not only do university campuses consist of a variety of social and educational buildings, they also create an integrated system with their outdoor spaces and furniture, recreation and landscape areas. Outdoors have the potential to create social interaction, rest and relaxation, recreation, exchange of ideas and a strong sense of ownership and belonging. Creating a common identity for social life by enabling people to communicate and socialize with each other is the most important function of outdoor spaces. However, although the rationality of external spaces is designed, it is possible to use other than what is expected in practice. The relationship between the external spaces and the building groups, the adequacy, the duration of use, the accessibility and the interaction of the physical environment should be examined with a holistic approach to understand the difference between expectations and reality. In order to identify user needs in outdoor spaces as a way to assess if human use and design intentions are in fact successful, post occupancy evaluation (POE) is recommended as the most significant advanced method. Unfortunately, although studies on the evaluation of indoor spaces have been increasing day by day, there is no comprehensive study of POE that can be applied to the outdoor spaces, especially in university campuses. In this study, a POE method which discusses the variables that affect the use of outdoor space and the interaction between these variables is introduced. The proposed method was applied in a suburban university campus and the results were evaluated in terms of outdoor use.

Keywords: Outdoor space; post-occupancy evaluation; university campus; spatio-temporal mapping.

'Sydney Üniversitesi Mimarlık Tasarım Planlama Okulu, NSW - Australia; ${ }^{2}$ Beykoz Üniversitesi, Mühendislik ve Mimarlık Fakültesi, Mimarlık Bölümü; İstanbul; ${ }^{3}$ Özyeğin Üniversitesi Mühendislik Fakültesi, Makina Mühendisliği Bölümü, İstanbul; ${ }^{4}$ Özyeğin Üniversitesi Mühendislik Fakültesi, Bilgisayar Mühendisliği Bölümü, Istanbul; ${ }^{5}$ Northumbria Üniversitesi Mimarlık ve Yapma Çevre Bölümü; Newcastle Upon Tyne, Ingiltere; ${ }^{6}$ Mimar Sinan Güzel Sanatlar Üniversitesi Mimarlık Fakültesi

Şehir ve Bölge Planlama Doktora Programı, İstanbul; ${ }^{7}$ Delft Teknoloji Üniversitesi, Elektrik Mühendisliği, Matematik ve Bilgisayar Bilimi; Delft, Hollanda 


\section{Giriş}

Ülkemizde genç nüfus yoğunluğunun fazla olması yeni üniversitelerin açılmasına yönelik bir talep oluşturmakta ve de mevcut üniversiteler üzerinde sürekli büyüme ve gelişme baskısı yaratmaktadır. Yeni üniversite ihtiyacı büyük oranda İstanbul'da karşılanmaktadır. Son 10 yılda İstanbul'da 22 yeni üniversite kurulmuştur. ${ }^{1} 2016$ yılı itibariyle İstanbul, 51 üniversite, 5 meslek yüksek okul ile yaklaşık olarak 1,5 milyon öğrenci nüfusuna sahiptir.

Büyüme ve gelişme talebini karşılamak için üniversiteler, kent içinde yer bulunamamasından ya da arsaların çok pahalı olmasından dolayı, yeni gelişmiş teknolojilerle donatılmış ve geniş arazilere yayılmış yerleşkelerini iletişim ve ulaşım araçlarındaki gelişmelerden de faydalanarak kent çeperlerinde ya da kent dışında kurmaktadırlar. Koç Üniv., Sabancı Üniv., Özyeğin Üniv., Işık Üniv., Arel Üniv. gibi çok sayıda kurum daha donanımlı ve mekânsal olarak yeterli alanlarda eğitim vermeyi hedefleyerek kent çeperinde ya da dışında yerleşkeler kurmuşlardır.

Sahip olduğu nüfus ve içerdiği işlevsel alanlar bakımından kentsel ölçekte bir yerleşme olarak ele alınabilecek bu yerleşkelerde birimler arası ilişkileri ve bu birimleri çevreleyen dış mekânların kullanım değerini araştırmak büyük önem taşımaktadır. Çünkü bu yerleşkelerde eğitim ve öğrenim faaliyetlerinin yanı sıra, birer yaşam alanı haline gelmişlerdir. Bina grupları arasında iç mekânla dış çevreyi bağlayan birer geçiş mekânı olan "dış mekân"ları oluşturan tasarım öğelerinin (mekânın büyüklüğü, niteliksel özellikleri, sağladığı mikroiklimsel ortam, içerdiği işlevsel bileşenler) kullanıcılar üzerindeki etkileri son yıllarda daha çok dikkati çeken bir konu olmuştur. Bu çalışmada üniversite yerleşkesinin dış mekânlarında uygulanabilecek zamanmekânsal haritalama yöntemine dayanan bir kullanım sonrası değerlendirme (KSD) (post-occupancy evaluation (POE)) yöntemi önerilmektedir.

Makalenin ilerleyen bölümlerinde (2. Bölüm) kent dışı yerleşkelerin oluşum süreci ve planlama ilkelerine ilişkin bilgiler yer almaktadır. 3. Bölümde dış mekânlarda zamanmekânsal haritalama tekniğine dayanan yöntem tanıtılmıştrr. 4. Bölümde çalışma alanı olarak seçilen Özyeğin Üniversitesi Çekmeköy yerleşkesi hakkında bilgiler verilmiştir. 5. Bölüm olan Bulgularda, (1) kullanıcı memnuniyetine, (2) mekân dizim yöntem ve davranışsal haritalamaya, (3) biyometeorolojik değerlendirmelere, (4) kameralardan elde edilen görüntüler ile coğrafi bilgi sistemleri (CBS) (geographical information systems (GIS) ortamında oluşturulan zaman-mekânsal haritalar yardımıyla mekânsal istatistik analizlerine ilişkin sonuçlara yer verilmiştir. 6. Bölüm olan Tartş̧ma/Sonuçta, çalışmadan elde edilen genel bulgular ve sonraki çalışmalara yön verecek hususlar tartışılmıştır.

1 http://www.yok.gov.tr/web/guest/universiteler (Son erişim tarihi: 21.02.2018).

\section{LiteratürÖzeti}

1950 'ı yıllara kadar kent içinde tekil ya da birkaç yapı grubundan oluşan örneklerine rastlanırken, üniversitelerin kent içinde belli bölgelerde dağılmış yapı gruplarından uzaklaşarak kent dışında büyük alanlara taşınmasıyla ülkemizde de yerleşke olgusundan söz edilmeye başlanmıştır. Türkiye'de ilk yerleşke örneklerinden olan Karadeniz Teknik Üniversitesi (1955, Trabzon), Ege Üniversitesi (1955, İzmir), Orta Doğu Teknik Üniversitesi (1956, Ankara) ve Atatürk Üniversitesi (1957, Erzurum) ile kent dışı yerleşkelerin sayısı da zaman içinde artmaya başlamıştır. Yıldız ve diğ. ${ }^{2}$ yürüttüğü çalışmada 2000lerden bu yana kurulmuş olan üniversitelerin büyük çoğunluğunun kent çeperinde ya da dışında tek bir yerleşke içinde olduğu belirtilmiştir.

Ülkemizde 1960'lı yıllardan sonra ivmelenen bu yaklaşımın başlıca nedenleri arasında

- öğrenci sayılarındaki artş̧ın gerektirdiği büyüme ve gelişme için intiyaçlara cevap verebilecek yeni binalara kent içinde yer bulunamaması ya da kent içindeki arsaların çok pahalı olması,

- iletişim ve ulaşım araçlarındaki gelişmelerin coğrafi uzaklık kavramını ortadan kaldırması,

- yeni gelişmiş teknolojilerle donatılmış yerleşkelerin üniversitenin kimliğinin ve saygınlığının simgesi haline gelmesi sayılabilir. ${ }^{3}$

Üniversite yerleşkeleri sadece çeşitli sosyal ve eğitsel yapılarından oluşmayıp, binalarıyla, dış mekânlarıyla, sosyal donatıları ve iyi bir mekân örgütlenmesiyle bir bütünlük sağlar. Farklı yaklaşımlar ve nitelikler yerleşkeleri birbirine benzetebilir ya da ayrıştırabilir. $O$ farklardan birisi yer seçimidir. Kent içi veya kent dışı yerleşkeler ve bu yerleşim kararının eğitim ve sosyal yaşama olumlu-olumsuz etkileri günümüzde en çok tartı̧ılan konulardan birisidir. Kurtoğlu ${ }^{4}$ çalışmasında yerleşkelerdeki sosyalleşme olgusuna dikkat çekmiş ve yerleşkeleri "entelektüel bir ortam sağlamak amacıyla farklı insanları ve onlara ait düşünceleri belli sınırlar içinde bir araya getirerek, sosyal alışverişe zemin sağlamak amacıyla kurulmuş üniversite kentleri" olarak tanımlamıştır.

Yılmaz ve dig. ${ }^{5}$ göre yerleşkeler, sadece bilimsel faaliyetlerin sürdürüldüğü ortamlar olmayıp, aynı zamanda öğrencilerin fiziksel ihtiyaçlarını karşılarken, sosyal ve kültürel gelişimlerine katkıda bulunan, öğrencilerin toplum içerisindeki davranışlarına ve toplum içerisindeki iletişim kabiliyetlerine olumlu yönde etki eden alanlardır. Yerleşke kullanıcıları olarak yalnızca öğrenciler değil, aynı zamanda çalışanların (akademisyen, idari ve teknik personel, taşeron firma çalışanları, işletmeciler vb.) da ihtiyaçlarının gözetilmesi bir "yaşam ortamı" olarak yerleşkelerin ele alınmasında önem taşımaktadır.

\footnotetext{
2 Yıldız ve diğ, 2016

Erkman, 1990.
} 
Kent dışındaki yerleşkelerin barınma, çalışma, dinlenme ve ulaşım gibi temel işlevleri karşılaması ve sahip olduğu nüfus yoğunluğunun (orta ölçekli yerleşkelerde 10.000 kişi civarında) fazla olması nedeniyle kentsel bir yerleşme olarak ele alınmaları gerekmektedir. ${ }^{6}$ Barındırdığı nüfus için çalışma işlevi (eğitim, öğretim ve araştırma faaliyetlerinin yürütülmesi için gerekli alanlar; örn. derslikler, çalışanlar için ofisler, kütüphane, laboratuvar vb.) dışında ulaşım, barınma, dinlenme, eğlence, yeme-içme ve rekreasyon işlevlerini de içeren bu yerleşkeler kendi kendine yetebilmektedir.

Bu nedenle kentsel yerleşme özelliği taşıyan bu yerleşkelerdeki yaşamın doğru bir biçimde planlanması farklı işlevleri barındıran birimler arasındaki ilişkilerin sağlanmasını ve bir bütün olarak çalışabilmesini gerektirmektedir. Bu ilkelerden en önemlisi birimler arasındaki ulaşım ağlarının (yaya ve araç) doğru biçimde kurgulanmasıdır. Yerleşkedeki işlevsel birimler arasındaki mesafe, birimler arasındaki ilişkinin güçlenmesinde etkili olmaktadır. Zengel ${ }^{7}$ yerleşkede yer alan birimler arasındaki ilişkilerin doğru kurulmasında belli başlı ulaşılabilirlik ölçütlerini sıralamıştır. Yerleşke binalarının organizasyonunda fakülteler arası ve ana fonksiyon grupları arasındaki mesafelerin ortalama yürüme standartlarına göre kurgulanmasının yerleşkenin kolay algılanabilir ve tanımlı olması için gerekli olduğunu ve bunun bilgi iletişimi ve sosyal bütünleşme açısından istenilen düzeyi yakalamada önemli bir rolü olduğunu vurgulamıştir. Polat $^{8}$ herkes için erişilebilir, yaya ölçeğinde, yeşil dokunun korunduğu ve sürdürüldüğü bir yerleşke niteliğine sahip olmanın önemini vurgulamıştir.

Ilgaz ${ }^{9}$ yerleşke tasarımının mekânsal, toplumsal ve politik bir bakış açısı ile ele alınması gerekliliği üzerine kurguladığı çalışmasında medeniyetin oluşumunda üniversitenin başarısını mekân, yer, insan davranışları, sosyal etkileşim, politikalar ve tüm bunların üniversite yerleşkesi ortamında birbiriyle olan ilişkisi ve bu kavramların bir fonksiyonu olarak elde edileceğini belirtmiştir.

Yapılan araştırmalardan çıkan ortak sonuç, mekânın fiziksel niteliklerinin mekânın verimli bir şekilde kullanımını etkilediği yönündedir. Yerleşkenin dış mekânlarının kullanıcı gereksinmelerine uygun donatılar içermesi (ağaçlık ve düz yeşil alanlar, su öğesi, heykel, oturma elemanları, toplanma alanları vb.) öğrenme mekânlarında yaşam kalitesini artrarak insan üzerinde duygusal rahatlamayı sağlayarak zihinsel sağlığı olumlu yönde etkilemektedir. ${ }^{10}$ Bu nitelikler genellikle dış mekânların kullanıcı beyanına dayalı öznel değerlendirmeler sonucunda (anketler, kullanıcı görüşmeleri vb. ile) ortaya konmaktadır. Yerleşke kullanımı üzerine yapılan araştrmalar genellikle yerleşkenin fiziksel niteliklerine (dış mekânlardaki oturma, gölgeleme donatıları, servis bi-

\footnotetext{
6 Erkman, 1990. $\quad{ }^{7}$ Zengel, $1998 . \quad 8$ Polat, 2015.

9 Ilgaz, $2014 . \quad \quad{ }^{10}$ Lau ve diğ., 2014.
}

rimleri vb.) ve bu niteliklerin kullanıcı tarafindan nasıl algılandığına odaklanmaktadır. ${ }^{11}$ Ancak çevresel nitelik aslında tüm bir alanın (mahalle, yerleşke, kent) karakteriyle ilgilidir. Dolayısıyla, yerleşke içindeki farklı dış mekânların bir bütün olarak ele alınarak nesnel etmenlere dayanarak değerlendirilmesi de dış mekân kullanımının anlaşııması için önemlidir. Dış mekânların üniversite yerleşkelerindeki sosyal hayatın ve kimlik algısının oluşmasındaki rolü dış mekânlarda gerçekleşen aktivite çeşitliliğine bağlıdır. Aktivite çeşitliliğinin yanı sıra belirli bir amaç ve tercihler doğrultusunda bir noktadan başlayıp diğer bir noktada son bulan dinamik bir süreç olarak tanımlanan yaya hareketinin gözlenmesi de dış mekân algısı hakkında fikir vermektedir. Yapılan yazın taraması sonucunda çıkarılabilecek sonuçlar şunlardır:

- Dış mekânlar üniversite yerleşkelerinin sosyalleşme, rahatlama, bir araya toplanma, ortak bir sosyal hayat ve kimlik oluşturma hedeflerinin gerçekleştirilmesinde önemli bir rol üstlenirler.

- Dış mekân kullanımında kullanıcı memnuniyetinin sağlanmasında, yerleşke ile kurulan aidiyet ilişkisi, mekânın fiziksel özellikleri, servis ve donatıların yeterliliği, ısıl konfor koşullarının karşılanması belirleyici rol oynamaktadır.

- Dış mekânlarda yürütülen çalışmalar şu başlıklar altında toplanmaktadır; (i) kullanıcı memnuniyet, (ii) mekân dizim ve davranışsal haritalama, (iii) biometeorolojik çalışmalar- ısıl konfor, (iv) kullanıcı takibi. Mekân kullanımını etkileyen değişkenlerin birbirileri ile olan ilişkilerini açıklayan bütünsel bir çalışmaya rastlanmamıştır.

- Dış mekânlarda yürütülen çalışmalarda üniversite yerleşkelerini konu eden çalışmalar sınırlıdır. Oysa Türkiye'de yeni üniversiteler açılmakta, bunların çok büyük bir kısmı ise kent dışı alanlarda kurulmaktadır ve bu yerleşkelerde kendi kendine yeterliliğin ne ölçüde sağlandığının belirlenmesi kritik önemdedir.

\section{Dış Mekanlar İçin Önerilen KSD Modeli}

Çalışma kapsamında önerilen zaman-mekânsal haritalama yöntemi (Şekil 1) dört ana başlığı içermektedir.

- Kullanıcı Memnuniyeti

- Mekân Dizimi ve Davranışsal Haritalama

- Biyometeorolojik Değerlendirmeler

o Dış Mekân Isıl Konfor Anketi

o Meteorolojik Ölçmeler

o Benzetim (Hesaplamalı Akışkanlar Dinamiği (HAD) (Computational Fluid Dynamics (CFD)) ve ENVIMet) Çalışmaları

- Kullanıcı Takibi

\footnotetext{
11 Yıldız ve Şener 2010; Çubukçu ve Isıtan, 2011; Erçevik ve Önal, 2011; Hussein \& Jamaludin, 2015; DeClercq, 2016.
} 


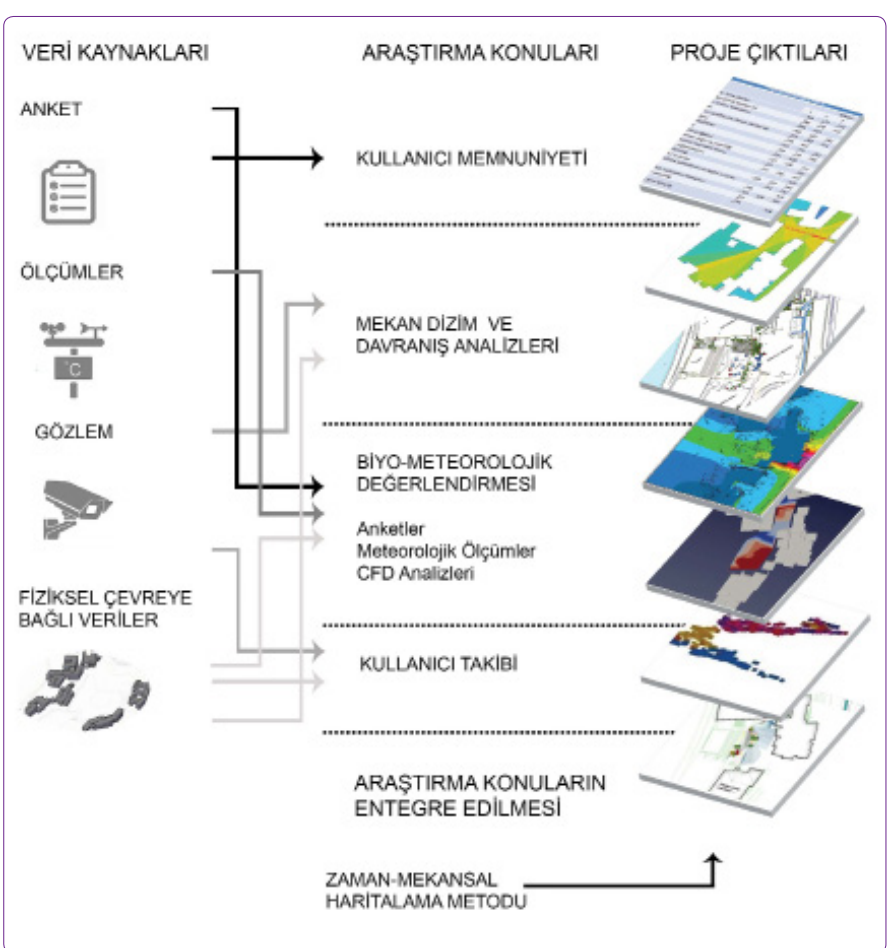

Şekil 1. Yöntemde araştırılan konuların entegrasyonu..$^{13}$

Mekânsal haritalama yöntemi kullanıcı, çevre ve mekâna ait verilerin tek bir veri tabanına dönüştürülerek CBS yardımıyla haritaların oluşturulmasına dayanır. Bu yöntemde farklı kaynaklardan elde edilen veriler (nicel/nitel), elde edildikleri mekânın kimlik numarasına göre bir veri tabanı oluşturacak biçimde yeniden düzenlenirler. Böylelikle kullanıcı ve çevreye ait verilerin mekânsal veriye dönüştürülmesi sağlanmış olur. Veri tabanı kullanılarak istenilen mekânsal haritalar oluşturulur. Bu yöntem geliştirilip zaman değişkeni bir boyut olarak eklenerek zaman-mekânsal haritalar elde edilebilmektedir. Zaman-mekânsal analizler insan, çevre ve mekâna ait değişkenlerin hem karşılıklı bir etkileşimi hem de kapsamlı bir birleşimi sonucunda oluşur. Her biri çeşitli derecelerde kullanım değeri üzerinde etkileri olan bu değişkenlerin bir arada ele alınabileceği gibi, etkilerini ayrı ayrı da ortaya koymak mümkündür. Bu haritaları oluşturmak için CBS yazılımlarından olan ArcGIS ${ }^{12}$ programı kullanılmıştır.

Şekil 1'de veri elde etmede kullanılan araç ve yöntemler, model kapsamında incelenen ana çalışma başlıkları ve çıktıların nasıl bütünleştirildiği görülmektedir.

\section{Uygulama}

\section{Çalışma Alanı: Özyeğin Üniversitesi}

Özyeğin Üniversitesi Eylül 2011'de Çekmeköy yerleşkesinde eğitime başlamıştır. Şekil 2'de görüldüğü gibi yerleşke Şile otoyolu ile 3.köprü bağlantı noktalarına yakın bir konumdadır.

\footnotetext{
${ }^{12}$ http://www.arcgis.com Son erişim tarihi: 21.02.2018. ${ }^{13}$ Göçer ve diğ. 2018a.
}

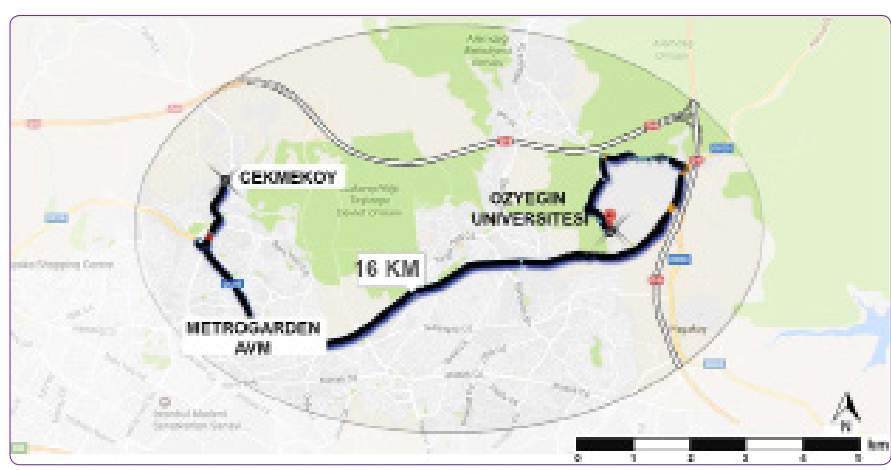

Şekil 2. Özyeğin Üniversitesi ve bağlantı yolları.

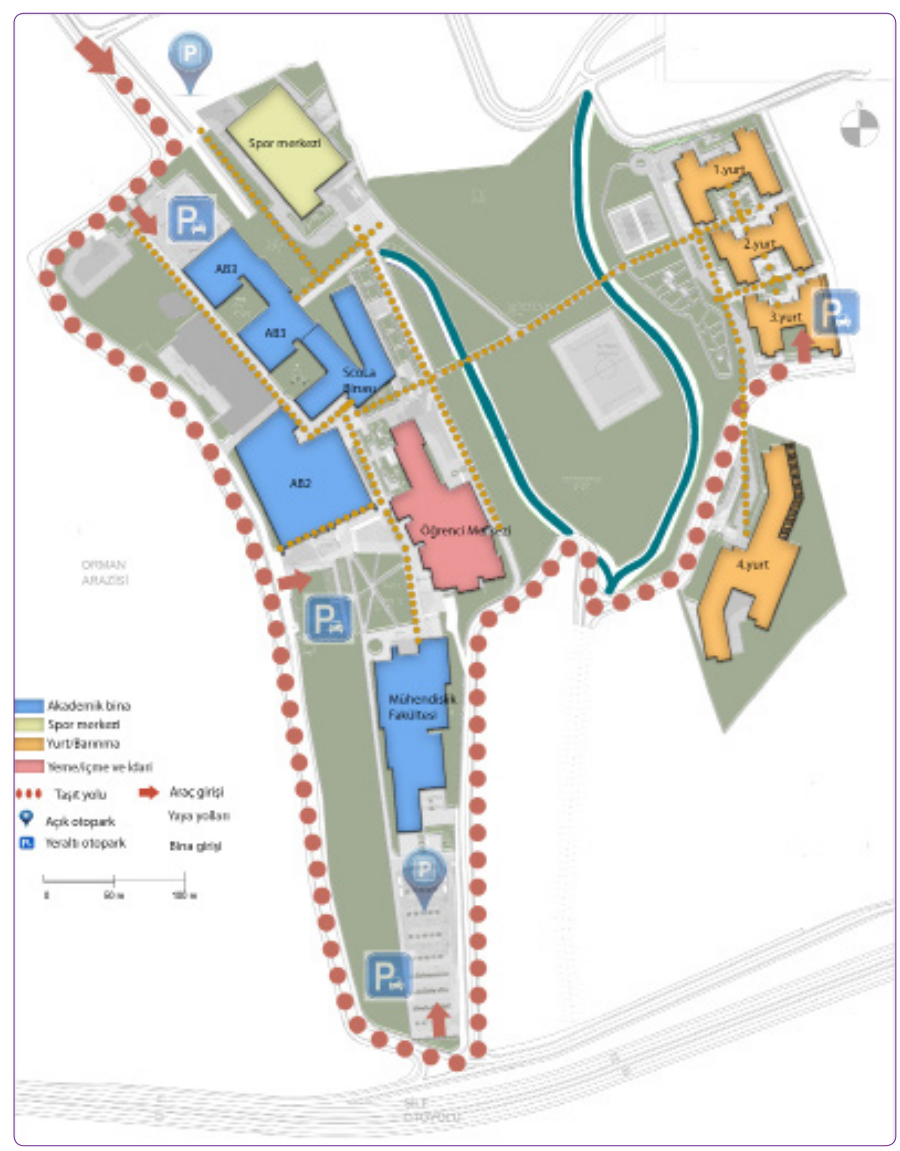

Şekil 3. Yerleşke arazi kullanımı ve araç/yaya ulaşımı.

Kent dışında yer alan yerleşkede eğitim ve idari binalar, yurtlar ve sosyal donatı alanları bulunmaktadır (Şekil 3). Toplam 220 bin metrekare alana kurulu yerleşkede, 5 fakülte ve 3 yüksekokul vardır. Özyeğin Üniversitesi Yerleşkesi'ni diğer yerleşkelerden farklı kılan ve onun kimliğini ortaya çıkaran özellikler; (i) binaların modern bir kimliğe sahip olması, (ii) binaların birbirleriyle yakın olması ve aralarında oluşan dış mekânların küçük toplanma alanları (quad) olarak kullanılması, (iii) eğimli topoğrafyayı bir firsat olarak değerlendirip binalara farklı kotlarından girerek binalar arası hareket sürekliliğinin sağlanmasıdır. Yerleşkenin çeşitli noktalarında kapalı ve açık otoparklar yer almakta- 
dır. Araç ve yaya ulaşımının kesiştirilmediği yerleşke tasarımında, işlevsel alanlar arasındaki mesafeler 10-15 dk'lık yürüme mesafesi içinde kalacak şekilde planlanmıştr. Yurtlar özellikle eğitim ve diğer alanlardan uzakta kurgulanmış, böylelikle barınma için daha sakin ve sessiz bir alan yaratılmıştır. Barınma ve diğer işlevsel alanlar arasında yer alan açık peyzaj alanları ise spor aktivitelerini içerecek biçimde düzenlenmiştir. Bu alanda tenis ve futbol sahası, yürüme parkuru ve piknik masaları yer almaktadır.

\section{Çalışmanın Ana Başıkları}

Çalışma 4 ana başıkta toplanmıştır; kullanıc memnuniyeti, mekân dizimi ve davranışsal haritalama, biyometeorolojik değerlendirmeler ve kullanıcı takibi.

\section{Kullanıcı Memnuniyeti}

Çalışmada öncelikle kullanıcı ihtiyaçlarının ve beklentilerin ne ölçüde karşılandığının tespit edilmesi için çalışan ve öğrencilerle açık uçlu ve çoktan seçmeli sorulardan oluşan anket çalışması yapılmıştır. 2016-2017 Eğitim ve Öğretim yılında yapılan memnuniyet anketine ait bilgiler (katılımcı sayısı, kathlımcılara ait tanımlayıcı özellikler, örneklem gru- bu yeterliliği vb.) Tablo 1'de yer almaktadır.

Dış mekâna ait niteliksel özelliklerin belirlenmesi için önemlilik derecelendirmesi, olgulara katlım ve niteliksel yeterlilik başlıklarından oluşan soruların ölçütleri Tablo 2 'de görülmektedir. Amaç kullanıcı profili, alışkanlıkları, etkinlik odaklı davranışları ve dış mekanlara ait niteliksel özelliklere ilişkin kullanıcı algısı hakkında bilgi toplamaktir.

\section{Mekân Dizimi ve Davranışsal Haritalama}

Mekân dizimi ve davranışsal haritalama yerleşkenin yoğun olarak kullanılan ana ulaşım aksı ve bu aks üzerinde yer alan binaları kapsayacak biçimde yürütülmüştür. Uzun bir aks üzerinde yapılan bu analizlerden elde edilen bulguları daha ayrıntılı tartş̧mak için yedi alt bölge oluşturulmuştur. Bölgelerin oluşturulmasında kullanıcı hareketleri (yürüme, toplanma ve geçiş alanlarının belirleyici rol oynadığı noktalar), ulaşım aksının fiziksel özellikleri (kırılmaya uğradığı, küçük ve büyük avlu oluşturduğu noktalar), topoğrafya, bina girişlerinin açıldığı noktalar belirleyici olmuştur (Alt bölgelerinde oluşturulmasında izlenen yöntem için daha

Tablo 1. Katılımcılara ait tanımlayıcı özellikler

\begin{tabular}{|c|c|c|c|c|c|c|c|c|c|}
\hline \multirow[t]{7}{*}{ ÖĞRENCI } & $\begin{array}{l}\text { Cinsiyet } \\
\%\end{array}$ & $\begin{array}{l}\text { Kadın } \\
48,8\end{array}$ & $\begin{array}{l}\text { Erkek } \\
46,6\end{array}$ & & & & & & \\
\hline & Fakülte & $\begin{array}{l}\text { Mimarlık ve } \\
\text { Tasarım Fak. }\end{array}$ & $\begin{array}{l}\text { Sosyal Bilimler } \\
\text { Fak. }\end{array}$ & İşletme Fak. & Mühendislik Fak. & Hukuk Fak. & $\begin{array}{l}\text { Havacılık ve Uzay } \\
\text { Bilimleri Fak. }\end{array}$ & $\begin{array}{l}\text { Uygulamalı } \\
\text { Bilimler YO. }\end{array}$ & $\begin{array}{l}\text { Yabancı } \\
\text { Diller YO }\end{array}$ \\
\hline & $\%$ & 37,9 & 39,2 & 6,7 & 10,9 & 14,6 & 35,3 & 15,8 & 27,0 \\
\hline & Bursluluk oranı & NA & $\% 25$ & $\% 50$ & $\% 75$ & $\% 100$ & & & \\
\hline & $\%$ & 13,8 & 26,1 & 40,8 & 4,8 & 14,5 & & & \\
\hline & Bitirdiği lise & Devlet Lisesi & Kolej & Anadolu Lisesi & İmam Hatip Lisesi & Teknik Lise & Fen Lisesi & & \\
\hline & $\%$ & 9,0 & 37,8 & 47,4 & 0,4 & 1,6 & 3,9 & & \\
\hline \multirow[t]{9}{*}{ ÇALIŞAN } & Cinsiyet & Kadın & Erkek & & & & & & \\
\hline & $\%$ & 68,4 & 31,6 & & & & & & \\
\hline & & Akademisyen & İdari personel & & & & & & \\
\hline & $\%$ & 58,0 & 42,0 & & & & & & \\
\hline & Yaş & $\leq 40$ & $41-50$ & $\geq 51$ & & & & & \\
\hline & $\%$ & 74,2 & 18,2 & 7,6 & & & & & \\
\hline & ÖzÜ'de çalışma & $<1$ yıl & $1-2 \mathrm{yıl}$ & $2-3$ yıl & $>3 \mathrm{yll}$ & & & & \\
\hline & Deneyimi & & & & & & & & \\
\hline & $\%$ & 22,7 & 15,8 & 10,2 & 56,9 & & & & \\
\hline
\end{tabular}

Anket çalışmasına 1041 öğrenci (toplam öğrenci sayısının \%19,6'sı) ve 304 çalışan (toplam çalışan sayısının \%43,6'sı) katılmıştır. Yapılan anketlerin sayısı istatistiksel olarak öğrenci grubu için 0,03 , çalışan grubu için ise 0.05 örneklem hatasına uydundur.

Tablo 2. Memnuniyet anketlerindeki algısal ölçütlerin tanımları

\begin{tabular}{ll} 
Dış mekâna ait niteliksel özellikler & Veri ölçüm birimleri \\
\hline Önemlilik derecelendirmesi: mimari bütünlük, temizlik, peyzaj özellikleri, & 1: hiçönemli değil 2: önemli değil \\
toplanma alanları, ulaşım ve algılanabilirlik & 3: nötr 4: önemli 5: çok önemli \\
Olgulara katılım: yerleşkenin mimari özelliklerine ilişkin olgular, güvenlik, & 1: kesinlikle katılmıyorum 2: katılmıyorum 3: nötr 4: katılıyorum \\
sosyalleşme, ısıl konfor & 5: tümüyle katılıyorum \\
Niteliksel yeterlilik:erişilebilirlik, mekân organizasyonu, dış mekân & 1: hiç yeterli değil 2: yeterli değil \\
tasarım öğelerinin ve donatılarının yeterliliği & 3: nötr 4: yeterli 5: oldukça yeterli
\end{tabular}


ayrıntılı bilgi Göçer ve diğ. ${ }^{14}$ ait çalışmada yer almaktadır). Davranış haritalarının oluşturulması için yerleşke doğrudan gözlemlenebilir alt alanlara bölünmüştür. Bu alanların, ölçümlenebilir, tanımlanmış kamusal dış mekânlar olmasına dikkat edilmiştir. Davranış haritalaması ile yerleşkenin kullanılan ve kullanılmayan alanları tespit edilerek, bu tespitler doğrultusunda kullanıcı davranış haritaları oluşturulmuştur. Mekân dizim analizi ile fiziksel çevreye bağlı olan durum tespit edilip yerleşkenin bütünleşik ve yalıtımış alanları ortaya çıkarılmıştır. Bütünleşme değerleri her aksın diğer tüm akslara olan adımsal uzaklığının hesaplanması sonucu elde edilmiştir. Yerel çap analizindeki yarıçap değeri üç olarak belirlenmiş olup (yarıçap:n) $(r: 3)$ literatürde genel olarak kabul edilen yerel bütünleşme hesaplanmasına uygundur. ${ }^{15}$ Gözlem çalışmaları, sabah 8.00 ile 18.00 arasında iki saatlik aralıklarla dört mevsim için yapılmıştır.

\section{Biyometeorolojik Değerlendirmeler}

Kullanıcıların deneyimledikleri mekânda ne derece konforlu oldukları da mikroiklimsel ölçmeler ve ısıl konfor anketleri ile araştırılmıştır. Isıl konfor çalışmaları kullanım analizi sonucunda yoğun olarak kullanıldığı tespit edilen alanlarda yapılmıştır. Bu alanlarda sabah, öğlen ve öğleden sonra olmak üzere dört mevsimde toplam 680 adet anket yapılmıştr. Anketlerde kullanııının demografik bilgileri, yaş, cinsiyet, uyruk, kilo ve boy oranı sorulmuştur. Görüşme yapılan kişinin özellikleri, ısıl konforun öznel olarak algılanması nedeniyle önemlidir. İkinci kısımda ısıl konfor açısından nasıl hissettikleri sorulmuştur ve soru tipine göre yedi ya da beş ölçekli sorular düzenlenmiştir. Son olarak kullanıcının ankete katılmadan önceki aktivite, kaldığı mekân ve o anda bulunduğu mekânda ne kadar süre vakit geçirdiği sorulmuştur. Bu yöntem Kruskal-Wallis olarak bilinmekte ve uzun-vadeli ısıl geçmişi öğrenerek mevcut durumu yorumlamak mümkün olmaktadır. ${ }^{16}$ Mikroiklimsel ölçmeler dış mekân ısıl konfor anketlerinin yapıldığı günlerde ve aynı zamanda $H A D$ analizleri için veri girdisi oluşturmada kullanılmak üzere üç farklı cihazla gerçekleştirilmiştir; (i) ışınım, rüzgâr hızı ve yönü, nem ve sıcaklığı ölçmek için kullanılan taşınabilir mini meteoroloji istasyonu (ii), Termo-Anemometre ve (iii) nem ölçer. Taşınabilir mini meteoroloji istasyonu, belirli bir noktadaki sıcaklığın genel durumunu ölçmek için 1,1 m yüksekliğe ayarlanmıştr. Taşınabilir cihazların yüksekliği, oturma ve ayakta duran kişiler için 0,6 ve $1,1 \mathrm{~m}$ olarak ayarlanmıştır. Bu taşınabilir cihazlar, görüşme saatinde görüşülen kişinin bulunduğu mikroiklimsel koşulları ölçmek için kullanılmıştır. ${ }^{17}$

Aynı zamanda HAD yöntemi ile yerleşkenin farklı iklimsel verilere göre de analizi yapılmıştr. ENVI-met programı ile ısıl konfor benzetimleri yapılmış, elde edilen sonuçlar ısıl konfor anket çalışmalarıyla karşılaştırılmıştır. Her iki

\footnotetext{
${ }^{14}$ Göçer ve dig. 2018b. $\quad{ }^{16}$ Wang ve diğ., 2016.

${ }^{15}$ Kim ve dig.,. 2002; Liu ve diğ., 2018. ${ }^{17}$ Bakovic ve diğ., 2017.
}

benzetim çalışması sonuçları mikroiklimsel ölçmeler ile karşılaştırılmış ve güvenilirliği sağlayacak doğrulamalar yapılmıştir. ${ }^{18}$

\section{Kullanıcı Takibi}

Yerleşkenin çeşitli noktalarına yerleştirilen kameralar aracılığıyla kullanıcı takibi yapılarak yerleşkenin en yoğun kullanılan alanları ve yürüme rotaları belirlenmiştir. Kameralarla yapılan kullanıcı takibinden elde edilen veriler CBS ortamına aktarılarak mekânsal ve zaman-mekânsal haritalar elde edilmiştir. Yerleşkede en yoğun kullanılan alanlar tespit edilip, bu alanlardaki ortalama komşuluk, ortalama ağırlık merkezi ve standart sapma elipsi analizleri yapılmıştır. Böylelikle mekânda dağılımın rastlantısal ya da kümelenmiş olup olmadığı, eğilimin doğrultusu ve mekân üzerinde nasıl bir yönde değiştiği ya da kaydığı mekânsal istatistik yöntemleri kullanılarak analiz edilmiştir. Tüm bu analizler yerleşkenin bütün bir yıl boyunca kullanıldığı dikkate alınarak mevsimsel etkileri de anlayabilmek için dört mevsim boyunca belirli günlerde yapılarak karşılaştırılmıştr. Haritalar farklı yöntemlerle elde edilen pek çok veri arasında ilişki kurmayı ve karşılaştırmalar yapmayı kolaylaştrarak verilerin görselleştirilmesine olanak sağlamıştr. Verilerin işlenmesi, istatistiksel ve sayısal modelleme teknikleri kullanılarak veriler arasında örüntülerin ve bağımlılık ilişkilerinin kurulması ile dış mekânlarda bütüncül bir KSD çalışması yapmak mümkün olmuştur.

\section{Bulgular}

Özyeğin Üniversitesi Çekmeköy Yerleşkesi'nde yürütülen çalışma sonrasında elde edilen bulgular aşağıda özetlenmiştir:

\section{Kullanıcı Memnuniyetine Ilişkin Bulgular}

Yerleşke kullanıcıları öğrenciler ve çalışanlar olmak üzere iki ana grupta incelenmiştir. Bu iki gruba ait kişisel özellikler yerleşke kullanımını etkilemektedir. Kullanıcıların yerleşkenin fiziksel ve sosyal olanaklarından memnun olduğu görülmüştür. Öğrencilere yerleşkenin üniversite tercihlerinde ne kadar etkili olduğu sorulmuş ve öğrencilerin $\% 72,8^{\prime} i$ tercihlerinde yerleşkenin etkili olduğunu belirtmiştir. Çalışanlar ise iş yeri tercihlerinde yerleşkenin etkili olduğunu (\%19,2'lik bir oran neredeyse her beş çalışandan biri) ve yerleşkeyi çekici bulduklarını belirtmişlerdir (çalışanların $\% 71,7$ 'si yerleşkenin çekici olduğunu düşünüyorum yargısına "tamamen kathlıyorum" ve "katlıyorum" şeklinde cevap vermişlerdir).

Her iki grupta da yerleşke kullanım değerini en fazla etkileyen değişken yerleşkeye ulaşımda kullanılan vasıta, bir diğer deyişle "araç sahipliliği" olmuştur. Yerleşkenin kent dışında olması ve toplu taşıma araçları ile ulaşımın neredeyse hiç olmaması nedeniyle ulaşım, kullanım değerini

${ }^{18}$ Bakovic ve Göçer, 2017. 
Tablo 3. Araçla yerleşkeye gelen çalışanlar ve hafta içinde yerleşkede vakit geçirme durumu ile ilgili ki-kare testi

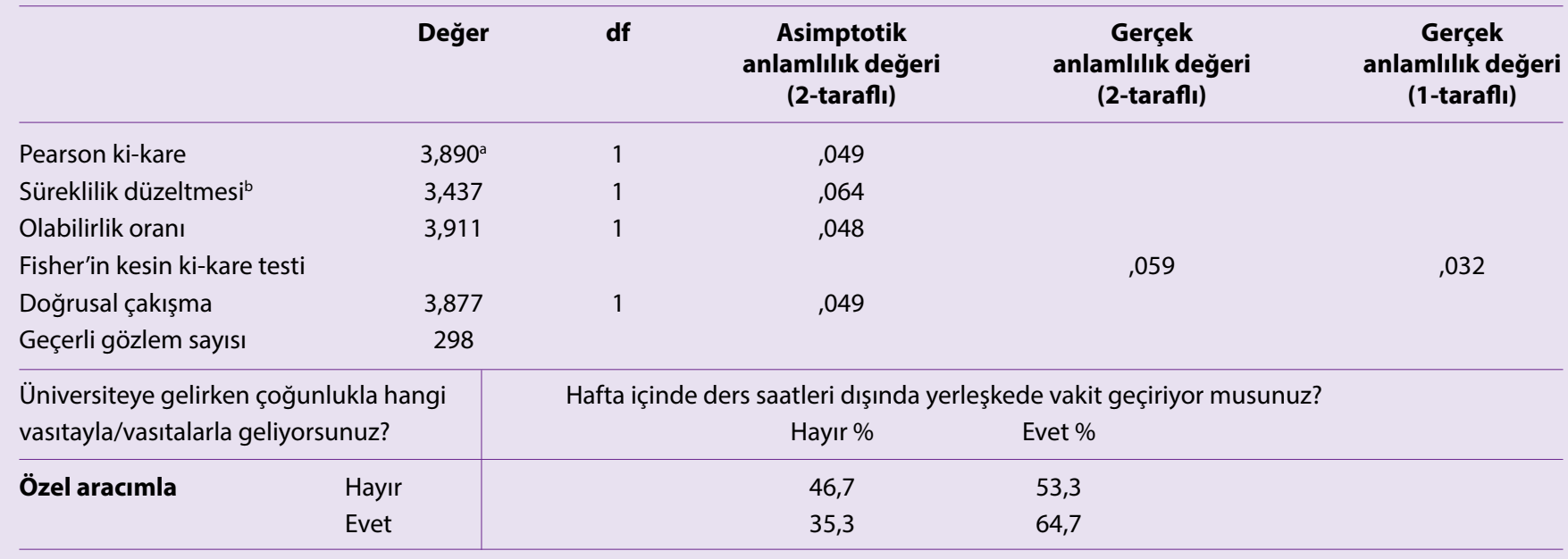

Tablo 4. Araçla yerleşkeye gelen öğrenciler ve hafta içinde yerleşkede vakit geçirme durumu ile ilgili ki-kare testi

\begin{tabular}{|c|c|c|c|c|c|}
\hline & Değer & df & $\begin{array}{c}\text { Asimptotik } \\
\text { anlamlılık değeri } \\
\text { (2-taraflı) }\end{array}$ & $\begin{array}{c}\text { Gerçek } \\
\text { anlamlılık değeri } \\
\text { (2-taraflı) }\end{array}$ & $\begin{array}{c}\text { Gerçek } \\
\text { anlamlılık değeri } \\
\text { (1-taraflı) }\end{array}$ \\
\hline Pearson ki-kare & $10,261^{\mathrm{a}}$ & 1 & ,001 & & \\
\hline Süreklilik düzeltmesib & 9,766 & 1 & ,002 & & \\
\hline Olabilirlik oranı & 10,018 & 1 & 002 & & \\
\hline \multicolumn{6}{|l|}{ Fisher'in kesin } \\
\hline \multicolumn{4}{|l|}{ ki-kare testi } & \multirow[t]{3}{*}{.002} & \multirow[t]{3}{*}{.001} \\
\hline Doğrusal çakışma & 10,251 & 1 & 001 & & \\
\hline Geçerli gözlem sayısı & 1000 & & & & \\
\hline \multirow{2}{*}{\multicolumn{2}{|c|}{$\begin{array}{l}\text { Üniversiteye gelirken çoğunlukla hangi } \\
\text { vasıtayla/vasıtalarla geliyorsunuz? }\end{array}$}} & \multicolumn{3}{|c|}{ Hafta içinde ders saatleri dışında yerleşkede vakit geçiriyor musunuz? } & \\
\hline & & & Hayır \% & Evet \% & \\
\hline \multirow[t]{2}{*}{ Özel aracımla } & Hayır & & 21,7 & 78,3 & \\
\hline & Evet & & 31,0 & 69,0 & \\
\hline
\end{tabular}

etkileyen en önemli unsur olarak ortaya çıkmaktadır. Ancak araç sahipliliği her iki kullanıcı grubunu aynı biçimde etkilememektedir. Öğrenciler ele alındığında öğrencinin kendi aracıyla yerleşkeye gelme oranı arttikça yerleşkede vakit geçirme oranı azalmaktadır. Yani araç sahipliliği ile yerleşke kullanımı arasında negatif bir ilişki vardır (Tablo 3). Çalışan grubuna bakıldı̆̆ında ise çalışanın kendi aracıyla yerleşkeye gelme oranı arttkça yerleşkede vakit geçirme oranı artmaktadır. Yani araç sahipliliği ile yerleşke kullanımı arasında pozitif bir ilişki vardır ${ }^{19}$ (Tablo 4).

Araç sahipliliği kullanıcının yerleşkeyle kurduğu ilişkiyi daha açık bir ifadeyle yerleşkede bulunduğu süreyi, bu süreyi nasıl geçirdiğini ve dolayısıyla yerleşkeden beklentilerini belirlemektedir. Bu sonuçlar Çubukçu ve Isıtan ${ }^{20} \operatorname{tara-}$ findan vurgulanan kullanıcıların beklentilerinin karşılanma

\footnotetext{
${ }^{19}$ Göçer ve Göçer, 2019.
}

düzeyinin yerleşkede geçirilen süreyi arttırdığı bilgisiyle örtüşmektedir.

Yerleşkede kullanıcı memnuniyetini artıran başarılı tasarım kararları şöyle özetlenebilir. Bina cephelerinde kullanılan malzemelerin ve detayların bir bütünlük oluşturacak şekilde tekrarlanarak yerleşkenin mimari kimliği oluşturulmuştur. Bu da yerleşkede bir dil birliği yaratmaktadır. Ayrıca çağdaş yapı malzemelerin ve geniş cam yüzeylerin kullanılması akıllarda yerleşkeye ilişkin olarak "modern" "yenilikçi" bir imge oluşmasını sağlamaktadır. Yurtlar ve idari birimler ile akademik binalar arasındaki ilişkilerin doğru kurgulanmasının da kullanıcı memnuniyetinin yüksek çıkmasında payı büyüktür. Bu sonuç Zengel'in ${ }^{21}$ "yerleşke binalarının organizasyonunda fakülteler arası ve ana fonksiyon grupları arasındaki mesafelerin ortalama

${ }^{21}$ Zengel, 1998. 
Tablo 5. Yerleşkedeki alt bölgelerin davranışsal ve mekânsal olarak karşılaştırılması

\begin{tabular}{lcccccc}
\hline Alt bölgeler & $\begin{array}{c}\text { Ortalama durağan } \\
\text { kişi sayısı }\end{array}$ & $\begin{array}{c}\text { Ortalama yürüyen } \\
\text { kişi sayısı }\end{array}$ & $\begin{array}{c}\text { Ortalama küresel } \\
\text { bütünleşme }\end{array}$ & $\begin{array}{c}\text { Ortalama yerel } \\
\text { bütünleşme }\end{array}$ & $\begin{array}{c}\text { Toplam } \\
\text { aks sayısı }\end{array}$ & $\begin{array}{c}\text { Aktivite } \\
\text { tipleri }\end{array}$ \\
\hline 1 & 45 & 113 & 0,40 & 0,52 & 10 \\
2 & 72 & 123 & 0,72 & 2,06 & 5 \\
3 & 42 & 415 & 0,87 & 0,66 & 3 \\
4 & 40 & 241 & 0,47 & 1,51 & 3 \\
5 & 245 & 230 & 0,62 & 0,52 & 3 \\
\hline
\end{tabular}

yürüme standartlarına göre kurgulanmasının yerleşkenin kolay algılanabilir ve tanımlı olması için gerekli olduğu ve bunun bilgi iletişimi ve sosyal bütünleşme açısından istenilen düzeyi yakalamada önemli bir rolü olduğu" tezini doğrulamaktadır. Yerleşkede ulaşılabilirlik ölçütleri Dober ${ }^{22}$ tarafindan verilen değerlere uymaktadır. $800-1000 m^{\prime}$ lik ve yaklaşık olarak 10-15 dakikalık mesafelerde kullanıcılar için dinlenme, yeme içme noktaları bulunmaktadır. Taşıt trafiği yerleşkenin dışına alınmış ve yaya hareketinin kesintisiz devam etmesi sağlanmıştır. Erçevik ve Önal'ın ${ }^{23}$ geniş alanlara yayılan kent dışı yerleşkeler için önerdikleri tasarım ilkelerinden birisi de tüm sosyal ve kültürel mekân ve aktivelerin merkezi bir alanda (meydan, yapı vb.) toplanmasıdır. Incelenen yerleşkede Öğrenci Merkezi olarak adlandırılan bina tüm bu fonksiyonları barındırdığından önemli bir çekim merkezidir ve yine yerleşkenin en büyük meydanına açıımaktadır. Öğrenci Merkezine akademik binaların yer altından bağlanması hem yapı içindeki yaya hareketinin sürekliliğini sağlamakta hem de kullanıcılar yağışlı, çok soğuk veya sıcak hava koşullarına asgari derecede maruz kalırlar.

\section{Mekân Dizim ve Davranışsal Haritalama Çalışmasına}

ilişkin Bulgular

Yerleşkenin günlük olarak kullanımına bakıldığında sabah saatlerinde 8.40 'dan sonra derslerin başlamasıyla bir hareketlilik görülmekte ve özellikle personel çıkış saati olan 17.00 ve öğrencileri şehir merkezine taşıyan akşam 18.00 servisinden sonra yoğunluk çok düşmektedir.

Yerleşkede gerçekleşen aktivite çeşitliliğine bakıldığında aktif aktivitelerde yürüme, durağan aktivitelerde ise oturma sıklıkla gerçekleşmektedir. Bu aktiviteler dışında uzanma ve koşma eylemleri gözlenmiş olup, yerleşkenin isteğe bağlı ve planmış aktiviteler açısından çeşitlilik içermediği söylenebilir. Bunun nedenleri arasında daha çok sayıda kullanıcı çekebilecek görünürlüğü yüksek ve yaya akışı üzerinde bulunan noktalarda gölgeli alanların ve oturma elemanlarının yetersiz olması söylenebilir. Aynı zamanda ısıl konfor açısından günün belli saatlerinde uygun olan mekânların ise servis aktiviteleri ve donatilardan yoksun olması kullanıcılar için bir çekim noktası olmasını

\footnotetext{
22 Dober, 2000.
}

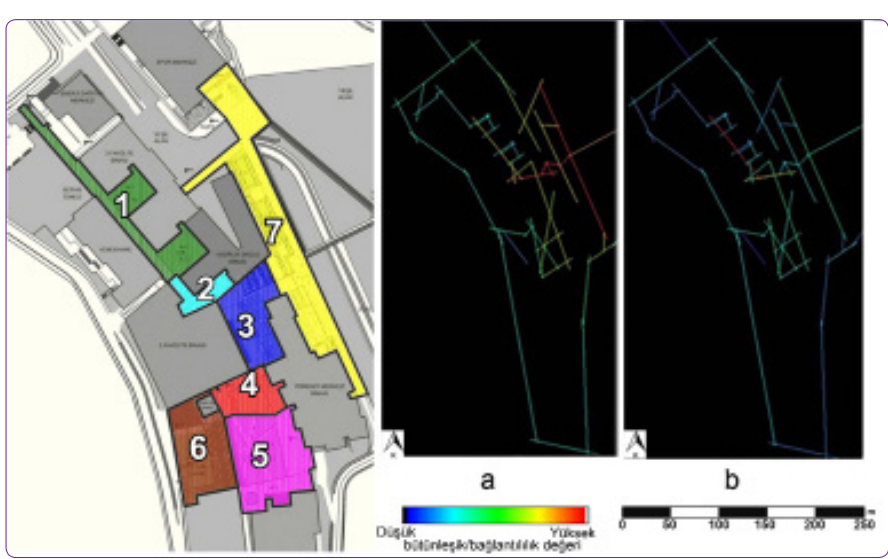

Şekil 4. Alt bölgeler ve alt bölgelere ait küresel bütünleşme haritası.

engellemektedir. Kullanıcılar yerleşkedeki tanımlanmış dış mekânların potansiyellerinden yeterince faydalanamamaktadır. Bunun en önemli nedeni dış mekânların yaya-odaklı donatilarla yeterince desteklenmiyor oluşudur. Yerleşke dış mekânlarının kullanım örüntüleri mekânsal örgütlenmenin sağladığı erişilebilirlik ve görülebilirlik seviyeleri ile örtüşmemektedir (Tablo 5, Şekil 4). Kısaca, yerleşkedeki dış mekânlar mekânsal örgütlenme açısından avantajı (yüksek görülebilirlik ve erişilebilirlik) olarak kurgulanmamış olduklarından ve kullanıcıları uzun süreli durağan aktiviteye teşvik edecek kullanıcı odaklı donatılar kısıtlı olduğundan bu mekânlar yeterince iyi işleyememektedirler. Örneğin planlanmış aktiviteler için büyüklük ve donat açısından uygun olabilecek tören alanı diğer mekânlardan yalıtılmış olduğundan ve herhangi bir servis alanı içermediğinden neredeyse hiç kullanılmamaktadır. Öğrenci Merkezinin önündeki orta avlunun yerleşkenin tek uzun süreli kullanım amaçlı dış mekânı olarak işlemesi büyüme potansiyeli olan üniversitenin gelecek dönemde ihtiyaçlarını tek başına karşılayamayacağını göstermektedir. Davranış haritalama sürecinde elde edilen bulgular Yıldız ve Şener' $\mathrm{in}^{24}$ değindiği bulgularla örtüşmektedir. Binalara yakın alanlarda kullanım yoğunlaşırken, açık alanlarda daha yaygın bir kullanım görülmektedir. Binalara yakın alanlarda kısa süreli aktiviteler gerçekleştirilirken örn. ayaküstü sohbet, sigara

\footnotetext{
${ }^{24}$ Yıldız ve Şener, 2010.
} 
Tablo 6. Cinsiyete göre dış mekân ısıl konfor koşullarının değerlendirilmesine ilişkin T testi

\begin{tabular}{|c|c|c|c|c|c|c|c|}
\hline & & Cinsiyet & Gözlem sayısı & Ortalama & Std. sapma & $\begin{array}{l}\text { Std. sapma } \\
\text { ortalaması }\end{array}$ & $\begin{array}{c}\text { Anlamlılık } \\
\text { değeri }\end{array}$ \\
\hline \multirow[t]{2}{*}{ SONBAHAR } & Nasıl hissediyor & Erkek & 64 & 3,5156 & 1,24712 & 15589 & ,035 \\
\hline & & Kadın & 56 & 3,0179 & 1,30022 & 17375 & ,035 \\
\hline \multirow[t]{2}{*}{ KIŞ } & Nasıl olsun & Erkek & 98 & 3,5918 & 81020 & 08184 & ,009 \\
\hline & & Kadın & 75 & 3,9067 & 71986 & ,08312 & ,008 \\
\hline \multirow[t]{6}{*}{ BAHAR } & Nasıl hissediyor & Erkek & 119 & 3,1597 & 1,13484 & 10403 & ,034 \\
\hline & & Kadın & 104 & 2,8462 & 1,04991 & 10295 & ,033 \\
\hline & Nasıl buluyor & Erkek & 119 & 1,9076 & 81294 & ,07452 & ,019 \\
\hline & & Kadın & 104 & 2,1635 & ,80183 & 07863 & ,019 \\
\hline & Nasıl olsun & Erkek & 118 & 3,5763 & ,92825 & ,08545 & ,000 \\
\hline & & Kadın & 104 & 4,0673 & 71413 & 07003 & ,000 \\
\hline \multirow[t]{4}{*}{ YAZ } & Nasıl hissediyor & Erkek & 92 & 4,0978 & 1,25846 & 13120 & ,003 \\
\hline & & Kadın & 65 & 3,4308 & 1,52037 & , 18858 & ,004 \\
\hline & Nasıl olsun & Erkek & 91 & 2,7363 & ,80049 & 08391 & ,003 \\
\hline & & Kadın & 64 & 3,1563 & 94648 & 11831 & ,004 \\
\hline
\end{tabular}

içme vb. açık alanlarda uzun süreli aktivitelere örn. ders çalışma, grup halinde oturma vb. rastlanmıştir.

Mekân dizim yöntemi kullanılarak yapılan araştırmalarda açık/kamusal alanların kullanım verimliliğini arttırmada alanın içinde bulunduğu mevcut doku ile bütünleşik olarak kurgulanması ve çevre dokudan rahat erişilebilir ve görülebilir olması gerektiği belirtilmektedir. Bu yaklaşım kapsamında yapılan çalışmalar, mekânsal kurgunun belirlediği erişilebilirlik (hareket alanları) ve görülebilirlik (görüş alanları) örüntüleri ile gözlemlenen kullanım ve hareket örüntüleri (insanların mekânda nerede bulunduğu) arasında istatistiksel bir ilişkinin olduğunu ortaya koymuştur. ${ }^{25}$ Yerleşke dış mekânlarında kullanıcılar arasındaki programlanmamış etkileşimin oluşması hem öğrenme süreci hem de sosyalleşme açılarından kritiktir. Dış mekânlardaki bu tür etkileşimler yerleşkeyi sağlıklı ve sürdürebilir kılmakta önemli rol oynamaktadırlar. Özellikle kent dışı bir yerleşkede ortak dış mekânlarda bu tür bir kolektif yaşamın sağlanması gerekmektedir. Dolayısıyla, tasarım açısından önemli olan, tüm yerleşke içinde fakülte binaları ile birlikte bütünleşik dış mekânlar tasarlayarak bu alanları uzun süreli kullanıma teşvik edici donatılarla desteklemektir. ${ }^{26}$

\section{Biyometeorolojik Değerlendirmelere iliş̧kin Bulgular}

Ankette katılımcıların içinde bulundukları dış mekandaki ısıl konfor algılarını 1'den (çok soğuk) 7'ye (çok sıcak) kadar derecelendirmeleri istenmiştir. Bir diğer soru ise kendilerini daha konforlu hissetmeleri için ortamın nasıl olması gerektiğine ilişkin sorudur. Bu sorunun seçenekleri de 1'den (daha soğuk) 5'e (daha sıcak) kadar derecelendirilmiştir. Dış mekândan ısıl konfor açısından beklentilerinin karşıla-

\footnotetext{
${ }^{25}$ Lerman ve diğ., 2014. $\quad{ }^{26}$ Özbil ve diğ., 2018.
}

nıp karşılanmadığına ilişkin memnuniyet sorusu ise 1 'den (hiç memnun değilim) 5'e (çok memnunum) kadar derecelendirilmiştir.

Kullanıcıya ait değişkenler cinsiyet, giysi türü, gerçekleştirilen aktivite, kilo/boy oranı ve maruz kalma (dış mekânda geçirilen süre) süresi, dış mekânda bulunma nedeni içerisinde kullanıcının dış mekân memnuniyetini istatistiksel olarak anlamlı bir farklılaşma yaratan değişkenler kilo/boy oranı ile dış mekânda bulunma nedeni olmuştur. Bu sorulara verilen cevaplarda cinsiyete göre anlamlı bir farklılaşma olup olmadığını incelediğimizde kadınlarla erkekler arasında şu farklılaşmalar ortaya çıkmıştır: Kadınların erkeklere göre ısıl konfor algıları daha düşüktür, bir diğer deyişle tüm mevsimlerde ortamı erkeklere göre daha az sıcak bulmuşlardır, nasıl olsun sorusuna verdikleri cevap tüm mevsimlerde (sonbahar hariç) erkeklere göre ortalamanın üstündedir (Tablo 6).

Kilo/boy oranı kathımcının kilosu ile boyunun oranını ifade eder; ankette bu ifade için üç seçenek sunulmuştur, (i) normal, (ii) kilolu, (iii) aşırı kilolu. Normal kilo/boy oranına sahip katılımcılar ile kilolular arasında anlamlı bir farkIılaşma $(p<0,05)$ görülmektedir. Normal kilo/boy oranına sahip katilımcılar kilolulara göre bulundukları ortamdan daha memnundurlar (Tablo 7).

Katilımcıların dış mekânda bulunma nedenleri memnuniyet yargılarına olumlu etkide bulunmaktadır. Yapılan $T$ testinde güzel havadan faydalanmak ve ders çalışmak için dış mekânda bulunduklarını ifade edenler ile bu soruya hayır yanıtını verenler arasında istatistiksel olarak anlamlı bir farklılaşma $(p<0,05)$ görülmektedir (Tablo 8). Belirli bir nedenden dolayı dışarıda olmayı tercih edenler bulundukları ortamdan daha memnundurlar. 
Tablo 7. Kilo boy oranına göre memnuniyete ilişkin Varyans analizi

\begin{tabular}{lcccccc}
\hline (I) Kilo boy oranı & (J) Kilo boy oranı & Ort. Fark (I-J) & Std. Hata & Anlamlılık Değeri & \multicolumn{2}{c}{$\mathbf{9 5 \% \text { Güven aralığı }}$} \\
\cline { 5 - 7 } & & & & & Alt sınır & Üst sınır \\
\hline \multirow{2}{*}{ Normal } & Kilolu &, $23256^{*}$ & 0,08607 & 0,019 & 0,0304 & 0,4347 \\
& Aşıı Kilolu & $-0,28234$ & 0,26219 & 0,529 & $-0,8982$ & 0,3335 \\
\hline
\end{tabular}

Tablo 8. Dış mekânda bulunma nedeni ile memnuniyete ilişkin T testi

\begin{tabular}{lcccccc}
\hline \multicolumn{2}{l}{ Dış mekânda bulunma nedeni } & Gözlem sayısı & Ortalama & Std. sapma & Std. sapma ortalaması & Anlamlılık değeri \\
\hline Güzel havadan & Hayır & 605 & 3,4777 & 0,87926 & 0,03575 & 0,06 \\
faydalanmak & Evet & 96 & 3,6563 & 0,73739 & 0,07526 & 0,034 \\
\hline
\end{tabular}

Dış mekânda yürütülen ısıl konfor çalışmalarında ısıl konfor algısının oluşmasında kişiye ait özelliklerin önemli olduğunu vurgulayan çalışmalarla ${ }^{27}$ elde edilen sonuçlar örtüşmektedir. Kullanıcıya ait kişisel özelliklerde cinsiyet, kilo/boy oranı ısıl algının oluşmasında farklılaşmalara neden olan değişkenler olarak bulunmuştur (Tablo 6, Tablo 7). Bu sonuç yazındaki kaynaklarla da örtüşmektedir. ${ }^{28}$

Bir diğer anlamlı sonuç ise ısıl konfor algısında fiziksel olmayan ve öznel değişkenlerin (manzara, ders çalışmak vb.) fiziksel koşullardan daha önemli bir rol oynadığı açıklanmasıdır (Tablo 8). Bu da Hwang ve $\mathrm{Lin}^{29}$ tarafindan yürütülen çalışmalarla örtüşmektedir. Middela ve diğ. ${ }^{30}$ ile Chen ve Edward ${ }^{31}$ çalışmalarında ısıl konforun dış mekân kullanımı ve kullanıcı davranışları üzerinde doğrudan etkisi olduğuna dair çıkarımlarda bulunmuşlardır. Kullanıcıların dış mekânda keyifli vakit geçirmeleri ve ısıl konfor açısından tatmin edici bir ortamın sağlanması aynı zamanda kentsel yaşam kalitesinin de artmasına neden olmaktadır.

Rüzgârın kuzeydoğudan estiği koşullarda yerleşke, yaklaşık 15 katlı binaların bulunduğu bir sitenin doğrudan etkisi altında kalmaktadır. Bunun hangi oranda olduğu anlamak amacıyla, sitenin çalışmaya dahil edildiği ve dahil edilmediği iki ayrı benzetim çalışması yapılmıştı. Şekil 5'te görüldüğü üzere sol taraftaki resim sitenin etkisinin çalışmaya dahil edildiği durumu göstermektedir. Diğer resimde ise, sitenin dahil edilmediği durumda hesaplanmış ortalama rüzgâr hız değerleri ve yönleri gösterilmektedir. İki durum arasında oluşan hava olayları arasındaki farklar göze çarpmaktadır. Sitenin göz ardı edildiği durumda daha güçlü bir jet yapısı oluşmakta ve alanın ortasında ölçümlerde gözükmeyen bir girdap yapısı meydana getirmektedir. İki sonuç arasındaki en

\footnotetext{
27 Mahmoud, 2011, Makaremi ve diğ. 2012.

2012; Lin ve diğ. 2014, Wang ve diğ. ${ }^{29}$ Hwang ve Lin, 2007.

2016; Hwang ve Lin, 2007.

${ }^{28}$ Karjalainen, 2007; Oliveira ve And- ${ }^{30}$ Middela ve diğ., 2014.
rade, 2007; Makaremi ve diğ., ${ }^{31}$ Chen ve Edward, 2012.
}

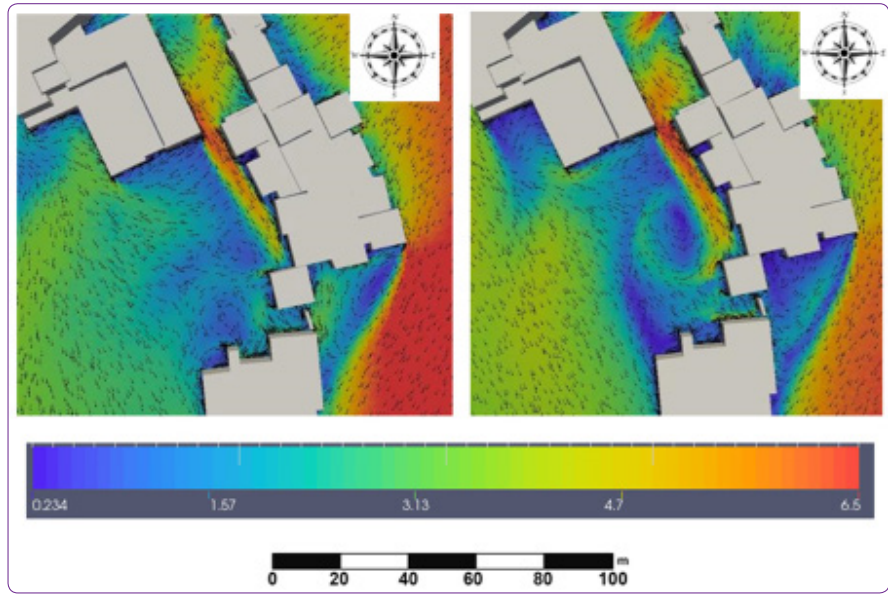

Şekil 5. Yerleşkenin kuzeybatısındaki sitenin modele dahil edildiği (sol) ve edilmediği (sağ) durumlarda hesaplanmış rüzgâr hız (m/sn) ve yön dağılımları.

göze çarpan sonuç jetin durumundaki bu farklıılık olarak gözükmektedir. Dolayısıyla, bu çalışmada bahsi geçen yüksek binanın modele katılmasının önemi gösterilmiş olmaktadır.

Yerleşkenin rüzgâr analizleri konfor değerlendirmelerinde rüzgârın etkisinin önemli olduğunu göstermektedir. Özellikle binaların birbirilerine göre olan konumu rüzgârın bazı noktalarda hızlanmasına ve türbülansların oluşmasına neden olmaktadır. Yapılan benzetim çalışmalarının ve ölçümlerin gösterdiği gibi; Öğrenci Merkezi ve AB2'nin birbirine yaklaştığı köşede rüzgâr sıkışması sonucu rüzgâr hızının önemli ölçüde arttğı gözlemlenmiştir. Bu noktadaki hız seviyelerinin konforu ciddi şekilde etkileyebileceği ve yerleşkedeki binaların konumlandırılması sırasında bu noktaya önem verilmesi tavsiye edilmiştir.

Dış mekân ısıl konfor çalışmalarında bir bilgisayar program olan ENVI-met kullanılmıştır. Bunun için yerleşkedeki mikroiklimsel koşulları gerçeğine en uygun şekilde benzetebilecek bir benzetim modeli oluşturul- 
muştur. Daha sonra bu model kullanılarak herhangi bir mikroiklimsel koşul için yerleşke dış mekanlarındaki ısıl konfor düzeyi benzetilebilir ve aynı zamanda yeni yapılacak binaların etkisi ve dahası bu bina çevrelerinde oluşturulabilecek dış mekanların ısıl konfor açısından değerlendirilmesi önceden hesaplanabilecektir. Programın kullanılabilirliğini test etmek üzere önce pilot çalışma yapılmış, ölçümlerle programın çıktıları karşılaştırılmıştır. Böylelikle programın doğruluğu test edilmiştir. Elde edilen PMV haritaları değerlendirildiğinde ENVI-met programının dış mekân ısıl konfor algılanmasında kullanılabileceği, doğruluğu kanıtlanmış "geçerli" çıktılar verdiği görülmüştür (Şekil 6).

\section{Kullanıcı Takibine Dayanan Zaman-Mekânsal}

Haritalama Yöntemi Sonucu Elde Edilen Bulgular

Özyeğin Üniversitesi Çekmeköy Yerleşkesi'nde bulunan kameralar yardımıyla dış mekânda kullanıcı takibi yapılmış ve kullanıcı takibi verileri CBS ortamına aktarılarak zamanmekânsal haritalar üretilmiştir. Kullanıcıların yerleşke içeri- sindeki dağılımları ve izledikleri rotalar hakkında bilgi veren bu haritalar ile mekânsal istatistik analizleri (ortalama ağırlık merkezi- mean center (MC) ve standart sapma elipsistandard deviational ellipse (SDE)) yapılmıştır. Dış mekânda bulunan pek çok kullanıcıyı tek bir noktayla ifade edebilen ortalama ağırlık merkezi kullanıcı hareketinin (noktanın) zamana bağı ı değişimini anlamamıza yardımcı olmaktadır. Standart sapma elipsi ise mekânın kullanımı ve hareketin doğrultusu hakkında fikir üretilmesine yardımcı olmaktadır.

Kullanıcı takibinden elde edilen haritalar üzerinde yapılan mekânsal istatistik analizleri (ortalama ağırlık merkezi ve standart sapma elipsi), yerleşke kullanımına ilişkin değerlendirmelerin istatistiksel olarak anlamlı ve belirli bir güven aralığındaki bilgilere dayandırımasını sağlamıştır. Yerleşkenin yürüme rotaları dışında daha uzun süreli aktiviteler için kullanılan ve meydan özelliği taşıyan üçdış mekânında yapılan bu analizler mevsimsel ve günlük farklılaşmaları ortaya çıkarmıştır. Mekân boyutlarının, mekânda bulunan işletmelerin (kafe, lokanta vb.), mekânda bulu-

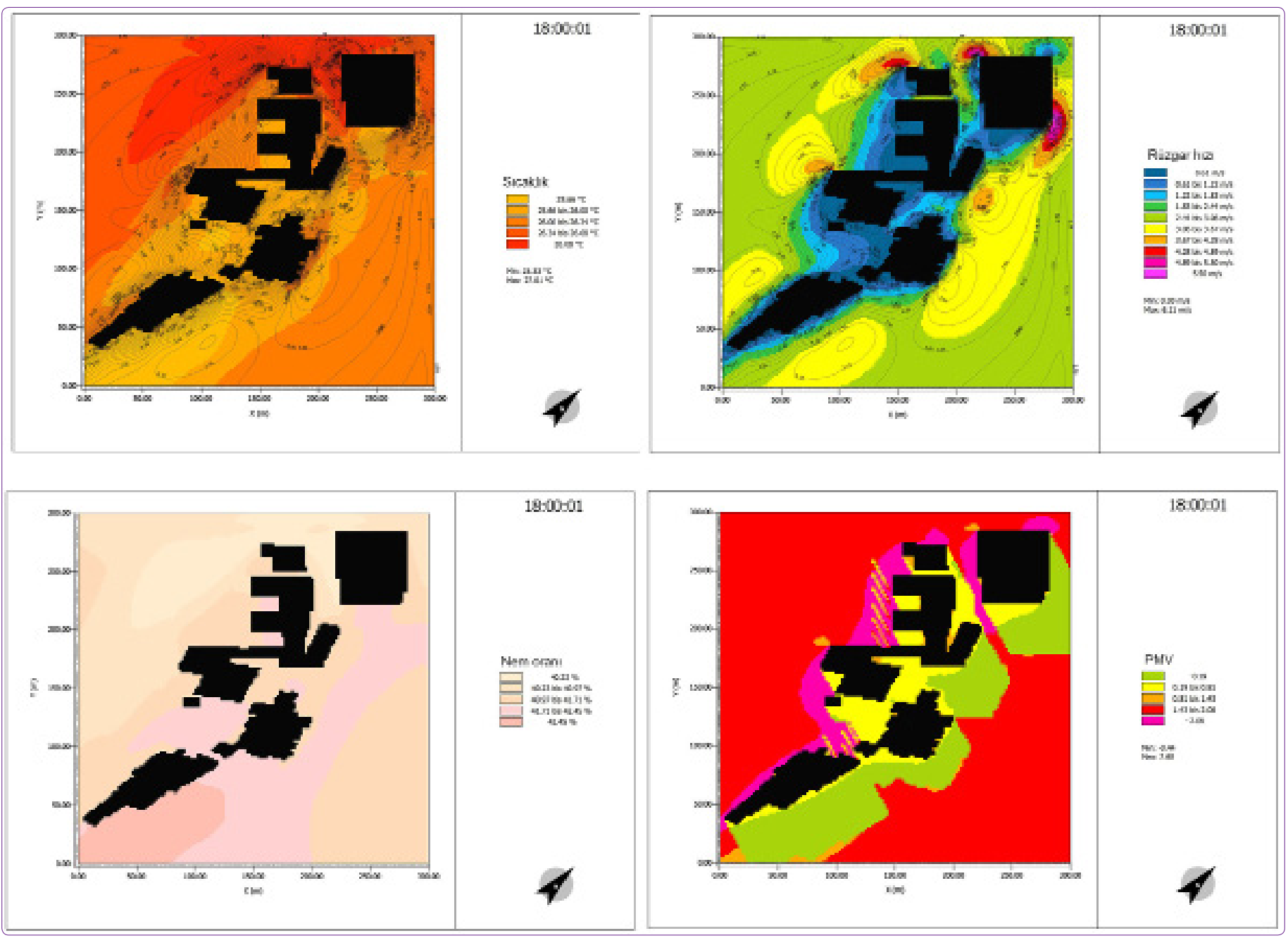

Şekil 6. ENVI-met programı ile oluşturulmuş Temmuz ayı için 12.00 saat aralığına ait mikroiklimsel ve ortalama ısıl duyum (predicted mean vote $(\mathrm{PMV})$ ) indeksi verileri. 


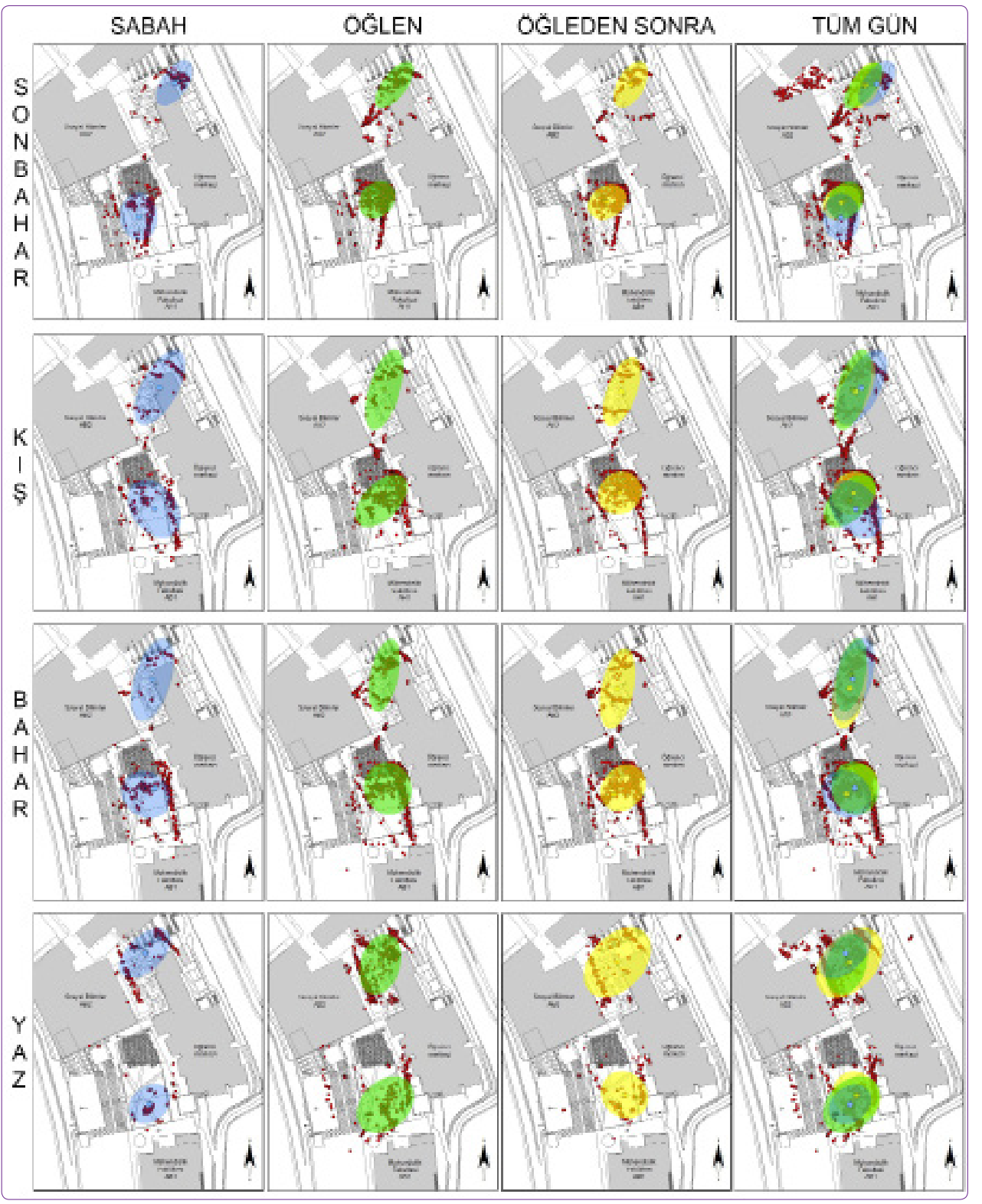

Şekil 7. 3 alt bölgede 4 mevsimlik ağırlık merkezi ve standart sapma elipsi analizi. ${ }^{32}$

nan donatiların (oturma elemanları, gölgelikler vb.), dış mekâna açılan giriş/çıkış kapılarının (iç mekân dış mekân ilişkisi kurulan noktalar) mevsimsel ve günlük analizlerde farklılaşmalara neden olan etmenler olduğu tespit edilmiştir. Mikroiklimsel etmenler kullanıcıların mekânda rastgele veya kümelenerek dağılım göstermesinde önemlidir. Yağışlı, soğuk, rüzgârlı, çok güneşli havalarda kümelenmelerin arttı̆̆ ve meydan kullanımının azaldığı görülmektedir. Meydanların kullanımını daralması veya genişlemesinde peyzaj elamanlarının ve gölgeleme elemanlarının yeterliliği önemli rol oynamaktadır. Konfor açısından uygun havalarda ise mekândaki işletmeler önemli çekim merkezi haline geldiğinden yine kümelenme görülmektedir.

Şekil 7'de tüm alt bölgeler ve bu bölgelere ait günlük ağırlık merkezi ve standart sapma elipsi analizleri mev- simsel olarak verilmiştir. Gün içerisinde değişimin anlaşılabilmesi için üç zaman dilimine göre yapılan analizler üst üste çakıştırılmıştır. Kümelenmeler meydanlardaki dağılımın rastlantısal olmadığını, meydanın belirli bir alanında diğer alanlara göre yoğunluk olduğunu göstermektedir (Şekil 7). Ağırlık merkezi analizi bize meydanın kullanım yoğunluğuna göre gerçek merkezin hangi noktaya doğru kaydığını gösterir. Örneğin kare bir meydanın geometrik olarak ağırlık merkezi meydanın tam ortasında yer alır. Eğer kullanıcıların meydan üzerindeki dağılımı rastlantısal ise bulunan ağılık merkezi ile geometrik ağırlık merkezi örtüşmüş olacaktır. Standart sapma elipsi ise elips formdan ziyade dairesel bir form alacaktır. Dairesel form kul-

\footnotetext{
${ }^{32}$ Göçer ve diğ., 2019
} 
lanıcı yoğunluğunun meydanın her noktasına eşit olarak dağıldığını ve bir yönlenme olmadığını ifade eder. Eliptik form kullanımın doğrultusunu işaret eder. Bazı durumlarda dağılım rastlantısal olsa bile meydanın formu kullanım biçimini de etkilediğinden standart sapma elipsi dairesel form almayabilir.

2. Alt bölgede ağırlık merkezinin ve standart sapma elipsinin çok fazla yer değiştirmediği görülmektedir. AğırIık merkezi de geometrik olarak alanın ortasına denk düşmektedir. Bunun nedeni bölgedeki tanımlanmış oturma alanlarının bölgenin her kenarına düzgün bir biçimde dağılmasından ve işletmelerin meydanın karşı iki noktasına yerleştirilmesinden kaynaklanmaktadır. Böylelikle ortalama ağılık merkezi meydanın orta noktasına yakın çıkmış, standart sapma elipsi ise çoğu analizlerde mekânın tamamına yakının kullanıldığını göstermiştir.

3. Alt bölgede ise en önemli farklılaşma elipsin doğrultusundadır. Günlük değişimler çok belirgin olmasa da mevsimsel değerlendirme yapıldığında önemli farklılaşmalar görülmektedir.

4-5. Alt bölgelerde (ana meydan) yer alan ve önemli bir çekim merkezi olan kafenin yanı sıra yoğun olarak kullanılan Öğrenci Merkezi girişinin bu farklılaşmada önemli bir rolü vardır. Bu da meydanın çok az bir kısmının yoğun olarak kullanıldığını, meydandaki diğer alanların daha az tercih edildiğini göstermektedir. Hem mevsimsel hem de günlük değerlendirme yapıldığında en büyük farklılaşma burada görülmektedir.

Sonuç olarak, bu yöntem dış mekân kullanımına yönelik karmaşık dokuların daha net algılanmasına ve görselleştirilmesine yardımcı olmuştur. Mikro iklimsel etkenlerin ve servis noktalarının kümelenme üzerindeki etkisi açık olarak görülmektedir.

\section{Sonuç}

Dış mekânlar için kapsamlı bir KSD yönteminin belirlenmesi hedefini taşıyan bu çalışma kent dışı bir üniversite yerleşkesi olan Özyeğin Üniversitesi Çekmeköy Yerleşkesi'nde uygulanmıştr. Dört ana başlık halinde yürütülen çalışma kapsamında elde edilen somut bulgular ışığında şu çıkarımlarda bulunmak mümkündür:

- Kent dışında kurulan yerleşkede, yerleşke kullanımını etkileyen en önemli faktörün hem çalışanlar hem de öğrenciler için "araç sahipliliği" olması dikkat çekici olmakla birlikte beklenen bir durumdur. Yerleşke kent dışında olmasının sağladığı avantajları iyi bir biçimde değerlendirmektedir. Ancak kullanıcılar üzerinde trafiğin yoğun olduğu saatlerden önce kent merkezlerine ulaşma isteğinin yarattğı bir baskı vardır. Bunun aşıımasında özellikle üniversiteye ulaşımın daha kolay sağlanmasını mümkün kılacak toplu taşıma araçlarının olması gerekliliğinin alt çizilmelidir. Bunu sağla- mak üniversite yönetiminin tek başına çözebileceği bir konu olmamakla birlikte, daha etkin bir ulaşım ağının kurulmasına ihtiyaç vardır.

- Üniversite dış mekanlarından bazılarının çok az yoğunlukta olduğu, bazılarında ise yüksek yoğunlukta bir kullanım görülmektedir. Bunun nedenleri arasında doğrudan dış mekâna açılmayan servis alanlarının yanı sıra yetersiz gölgeleme elemanlarının ve gölgeleme elemanları ile bütünleşik oturma ve dinlenme elemanlarının tasarlanmamış olması söylenebilir. Gölgeleme elemanı sayısının artırılması için çok büyük bir ihtiyaç vardır. 2011 yılında kurulan yerleşkede ağaçlar henüz yeterince gölge yapmadığından bu ihtiyaç mevcut elemanlarla karşılanamamaktadır.

- Özellikle ana meydanın yoğunluğunu azaltmak için az yoğunluklu dış mekanlarda yeni çekim noktaları yaratmak gerekliliği gözlenmiştir. En dikkat çekici alan neredeyse bütün bir yıl boyunca hiç kullanılmayan tören alanıdır. Bu alan hem büyüklük hem de manzara açısından oldukça önemli bir potansiyele sahiptir. Bu alanın bir etkinlik meydanı olarak ele alınıp canlandırılması gerekmektedir.

- Çalışma sırasında değinilen diğer bir intiyaç ise dış mekanlardaki sanatsal donatıların eksikliğidir. Heykel, yontu ve diğer sanatsal öğelerin arttırılması mekanların çekim gücünün artmasına ve simgesel buluşma noktası olmasına neden olacaktır.

Dış mekanların değerlendirilmesine ilişkin olarak bir KSD yöntemini içeren bu araştırmanın sonuçlarından yola çıkarak bundan sonra yapılacak araştırmalar için aşağıdaki öneriler sunulabilir;

- Yerleşkelerin zamanla değişen ve gelişen organizasyonlar olduğu fikrinden hareketle çalışma sonraki yıllarda yeniden tekrarlanabilir, böylelikle yerleşkedeki yeni yapılaşmaların mikroiklimsel çevre üzerindeki etkisi görülmüş olur veya nüfus artı̧ının mekân kullanımına etkisi araştırılabilir.

- HAD ve ENVI-met benzetim modelleri kullanılarak aynı çalışma alanı için gelecekte yapılacak binaların oluşturacağı etkiler veya şu anda tespit edilen sorunlara çözüm önerileri tartışılabilir.

- İstanbul ilinde bulunan bir kent dışı üniversite yerleşkesine uygulanan KSD yöntemi aynı ilde farklı bir kent dışı/kent içi üniversitede uygulanabilir. Aynı ilde uygulanacak çalışmada yerleşke tasarımının farklılaşmalar üzerindeki etkisi görülebilir.

- Bu yöntem farklı illerde denenerek iklimsel farklılaşmaların etkisi araştrılabilir.

- Dış mekanlar için önerilen bu yöntem farklı işlevlere sahip diğer yapı grupları (hastane, otel, sanat merkezi vb.) arasında kalan dış mekanlara uygulanabilir. 
- Kamera görüntülerinin CBS ortamına aktarılarak sayısallaştırılması yöntemi farklı çalışma alanlarında kullanılabilir.

- Çalışmanın ölçeği daha büyük ölçekte kentsel alanlara (meydanlar, parklar, kıyı alanları vb.) uygulanabilir.

Sonuç olarak barınma, çalışma, dinlenme ve ulaşım gibi temel işlevleri karşılayan kent dışındaki yerleşkelerin, sahip olduğu nüfus yoğunluğu (orta ölçekli yerleşkelerde 10.000 kişi civarında) dikkate alındığında kentsel bir yerleşme olarak ele alınmaları gerekir. Yerleşkeler sadece çeşitli sosyal ve eğitsel yapılarından oluşmayıp binalarıyla, dış mekânlarıyla, sosyal donatılar ve iyi bir mekân örgütlenmesiyle bir bütünü sağlar. Kullanıcıları için çaIışma işlevi (eğitim, öğretim ve araştırma faaliyetlerinin yürütülmesi için gerekli alanlar; örn. derslikler, çalışanlar için ofisler, kütüphane, laboratuvar vb.) dışında ulaşım, barınma, dinlenme, eğlence, yeme-içme ve rekreasyon işlevlerini de içeren bu yerleşkeler kendi kendine yetebilmelidir. Farklı işlevleri barındıran birimlerden oluşan yerleşkelerde birimler arasındaki ilişkilerin sağlanabilmesi ve bir bütün olarak çalışabilmesinde planlamanın belirli ilkeler doğrultusunda yapılması gerekmektedir. Ancak planlama aşamasında alınan kararların kullanım aşamasında ne kadarının gerçekleştirilebildiği veya doğru sonuçlar verip vermediğini değerlendirmek tasarım sürecinin son halkası olan geri bildirimin sağlanması için oldukça önemlidir. $^{33} \mathrm{Bu}$ nedenle KSD çalışmalarına ilgi her geçen gün artmaktadır.

Özetle; Yerleşkeler üzerinde yapılan çalışmalar genellikle yerleşke dış mekânlarının fiziksel niteliklerine ve bu niteliklerin kullanıcılar tarafindan nasıl algılandığına odaklanmaktadırlar. Kullanıcıların mekânı kullanma pratikleri ve nedenleri çoğunlukla kullanıcı anketleri veya kısıtlı gözlemler ile ölçümlenmektedir. Ancak bu tür veriler yerleşkelerin kullanım pratiklerine ve bu tercihlerin altında yatan sebeplere ilişkin nesnel sonuçları ortaya koymakta yetersiz kalmaktadır. Bu çalışmada, kent dışı bir üniversite yerleşkesindeki kullanıcıya ait verilerin nedensellikleri çok farklı açılardan yorumlanmıştır. Farklı çalışma konularının bütünleştirilmesi ile yerleşke dış mekânlarındaki kamusal yaşamı etkileyen fiziksel ve mekânsal ölçütler belirlenmiştir.

\section{Teşekkür}

Bu çalışma TÜBITAK $115 Y 225$ nolu Zaman-Mekânsal Haritalama Yöntemi ile Üniversite Yerleşkelerinde Dış Mekânların Kullanım Sonrası Değerlendirmesi başlıklı proje kapsamında yürütülmüştür.

${ }^{33}$ Göçer, Ö., Hua, Y., \& Göçer, K. (2015). Completing the missing link in building design process: Enhancing post-occupancy evaluation method for effective feedback for building performance. Building and Environment, 89, 14-27.

\section{Kaynaklar}

Bakovic, M. ve Göçer, Ö., (2017). Envi_Met Modeling Of Green Roof Effects On Microclimate And Outdoor Thermal Comfort, The 12 th Conference on Sustainable Development of Energy, Water and Environment System- SDEWES Conference, October 4-8, 2017, Dubrovnik, Croatia

Bakovic, M., Siddiqui, F., Başol, M.A., and Göçer, Ö., (2017). Outdoor Thermal Comfort Analysis at a Sustainable University Campus.International Symposium to Promote Innovation \& Research in Energy Efficiency- INSPIRE Symposium, 27 th November- 1 st December, Jaipur, India.

Chen, L. ve Edward, N. 2012. Outdoorcomfort and outdoor activities: A review of research in the past decade", Cities, 29, 118-125.

Çubukçu, E. ve Isıtan, Z. N. 2011. Does student behavior differ in relation to perception/evaluation of campus Environments? A post-occupancy research in two university campuses. Gazi University Journal of Science, 24(3), 547-558.

DeClercq, C. (2016). Toward the Healthy Campus: Methods for Evidence-Based Planning and Design. Planning for Higher Education, 44(3), 86.

Dober, R.P., 2000. Campus landscape, functions, forms and features, John Wiley \& Sons, Inc

Erçevik, B. ve Önal, F. 2011. Üniversite Yerleşke Sistemlerinde Sosyal Mekân Kullanımları MEGARON;6(3):151-161.

Erkman, U., 1990. Büyüme ve Gelişme Açısından Üniversite Yerleşkelerinde Planlama Ve Tasarım Sorunları, i.T.Ü. Mimarlık Fakültesi Baskı Atölyesi.

Göçer, Ö., Göçer, K., Başol, A. M., Kıraç, M. F., Özbil, A., Bakovic, M., ...; Özcan, B. (2018a). Introduction of a spatio-temporal mapping based POE method for outdoor spaces: Suburban university campus as a case study. Building and Environment, 145, 125-139.

Göçer, Ö., Torun, A. O., \& Bakoviç, M. (2018b). Kent dışı bir üniversite kampüsünün dış mekânlarında ısıl konfor, kullanım ve mekân dizim analizi [Thermal comfort, behavioral mapping and space syntax analysis of outdoor spaces in a suburban campus]. Gazi Üniversitesi Mühendislik-Mimarlık Fakültesi Dergisi, 33(3), 853-873.

Göçer, Ö., ve Göçer, K. (2019). The effects of transportation modes on campus use: A case study of a suburban campus. Case Studies on Transport Policy, 7(1).

Göçer, Ö., Göçer, K., Özcan, B., Bakovic, M., \& Kıraç, M. F. (2019). Pedestrian tracking in outdoor spaces of a suburban university campus for the investigation of occupancy patterns. Sustainable cities and society, 45, 131-142.

Hussein, H., \& Jamaludin, A. A. (2015). POE of Bioclimatic Design Building towards Promoting Sustainable Living. Procedia-Social and Behavioral Sciences, 168, 280-288.

Hwang, R.L. ve Lin T.P. 2007. "Thermal comfort requirements for occupants of semioutdoor and outdoor Environments in hothumid regions". Architectural Science Review;50:60-7.

Ilgaz, B., 2014. Mekânsal, Toplumsal ve Politik Değerlendirmede Üniversite Yerleşke Tasarımı, Orta Doğu Teknik Üniversitesi, Fen Bilimleri Enstitüsü, Yayınlanmamış Yüksek Lisans Tezi.

Karjalainen, S. 2007. Gender Differences in Thermal Comfort and Use of Thermostats in Everyday Thermal Environments." Building and Environment, 42(4): 1594-603.

Kim, H. K., \& Sohn, D. W. (2002). An analysis of the relations- 
hip between land use density of office buildings and urban street configuration: Case studies of two areas in Seoul by space syntax analysis. Cities, 19(6), 409-418) ( Liu, P., Xiao, X., Zhang, J., Wu, R., \& Zhang, H. (2018)

Kurtoğlu, A. 2010. Yerleşke Tasarımında Eylem Yönlendiricisi İle Sosyal Etkileşimin Değerlendirilmesi, İstanbul Teknik Üniversitesi, Fen Bilimleri Enstitüsü Yayınlanmamış Yüksek Lisans Tezi.

Lau, S. S. Yu, Z. Gou, and Y. Liu. 2014. Healthy campus by open space design: Approaches and guidelines." Frontiers of Architectural Research 3.4 452-467.

Lerman, Y., Rofè, Y. ve Omer, I. 2014. Using Space Syntax to Model Pedestrian Movement in Urban Transportation Planning Geographical Analysis Volume 46, Issue 4, Pages 392-410.

Lin, T. Y., Maire, M., Belongie, S., Hays, J., Perona, P., Ramanan, D., ... \& Zitnick, C. L. (2014, September). Microsoft coco: Common objects in context. In European conference on computer vision (pp. 740-755). Springer, Cham.

Liu, P., Xiao, X., Zhang, J., Wu, R., \& Zhang, H. (2018). Spatial Configuration and Online Attention: A Space Syntax Perspective. Sustainability, 10(1), 221

Mahmoud, A. H. A.. 2011. Analysis of the microclimatic and human comfort conditions in an urban park in hot and arid regions. Building and Environment 46.12: 2641-2656.

Makaremi, N., vd. 2012.Thermal comfort conditions of shaded outdoor spaces in hot and humid climate of Malaysia, Building and Environment 48: 7-14.

Middela, A. vd. 2014. Impact of urban form and design on midafternoon microclimate in Phoenix Local Climate Zones, Landscape and Urban Planning, 122, 16- 28.

Oliveira, S, ve Andrade, H. 2007. An initial assessment of the bioclimatic comfort in an outdoor public space in Lisbon, Inter- national Journal of Biometeorology;52:69-84.

Özbil, A., Göçer, Ö., Bakovic, M., \& Göçer, K. (2018). A quantitative investigation of the factors affecting patterns of occupation in a suburban campus: The case of ozyegin university in Istanbul. ArchNet-IJAR, 12(2).

Özbil, A., Göçer, Ö., Bakovic, M., \& Göçer, K. (2018). A quantitative investigation of the factors affecting patterns of occupation in a suburban campus: The case of Ozyegin University In Istanbul. ArchNet-IJAR: International Journal of Architectural Research, 12(2), 98.

Polat, B. 2015. Üniversite Yerleşke Alanlarında Tasarım Sorunu, Analitik İnceleme ve Bir Öneri Dokuz Eylül Üniversitesi Fen Bilimleri Enstitüsü Yayınlanmamış Yüksek Lisans Tezi.

Wang, Y., ve diğ., 2016. Thermal comfort in urban green spaces: a survey on a Dutch university campus. International journal of biometeorology,1-15.

Yıldız, B. Y., Çil E., ve Can I.. 2016. Yerleşke Morfolojisi: Bir Yaşam Alanı Olarak Üniversite YerleşkelerininAnalizi."https://www. academia.edu/BO Son erişim tarihi: 21.02.2018

Yıldız, D. ve Şener, H. 2010. Binalarla tanımlı dış mekânların kullanım değeri analiz modeli. iTÜDERGisi/a, 5(1), 115-127.

Yılmaz, T. Gökçe, D. Şavklı, F. Çeşmeci, S. 2012. Engellilerin Üniversite Yerleşkelerinde Ortak Mekânları Kullanabilmeleri Üzerine Bir Araştırma: Akdeniz Üniversitesi Olbia Kültür Merkezi Örneği, Tekirdağ Ziraat Fakültesi Dergisi, Journal of Tekirdag Agricultural Faculty 9 (3), 1-10.

Zengel, R. 1998. An evaluation of campus planning in settlement patterns with regard to the criteria of ccessibility, Üniversite yerleşke planlamasında yerleşim dokularının ulaşılabilirlik kriteri ışığında incelenmesi, Dokuz Eylül Üniversitesi, Yayınlanmamış doktora tezi. 